TAPROBANICA, ISSN 1800-427X. April, 2020. Vol. 09, No. 01: pp. 39-49, pls. 15-18. (C) Research Center for Climate Change, University of Indonesia, Depok, Indonesia www.taprobanica.org

\title{
TAXONOMY AND DISTRIBUTION OF Liopeltis calamaria (GÜNTHER, 1858) (REPTILIA: COLUBRIDAE), INCLUDING REDESCRIPTION OF THE SYNTYPES
}

\section{A. A. Thasun Amarasinghe ${ }^{1,6}$, Suranjan Karunarathna ${ }^{2}$, Patrick D. Campbell ${ }^{3}$,} S. R. Ganesh ${ }^{4} \&{\text { Gernot } \text { Vogel }^{5}}^{5}$

${ }^{1}$ Research Center for Climate Change, University of Indonesia, Gd. PAU Lt. 8.5, Kampus UI, Depok 16424, Indonesia

${ }^{2}$ Nature Explorations \& Education Team, No: B-1 / G-6, De Soysapura Flats, Moratuwa 10400, Sri Lanka

${ }^{3}$ Department of Life Sciences, Darwin Centre, Natural History Museum, Cromwell Road, South Kensington, London SW7 5BD, England

${ }^{4}$ Chennai Snake Park, Rajbhavan Post, Chennai 600 025, Tamil Nadu, India

${ }^{5}$ Society for Southeast Asian Herpetology, Im Sand 3, D-69115 Heidelberg, Germany

${ }^{6}$ Association of Asian Herpetology (Asosiasi Herpetologi Asia), Jl. BSD Bintaro No. 88, Pondok Aren 15228,

Tangerang Selatan, Indonesia

${ }^{1}$ Corresponding author. E-mail: thasun@rccc.ui.ac.id

\section{Abstract}

Liopeltis calamaria, a rare non-venomous colubrid snake of South Asia, is redescribed. Its syntypes and all the available type specimens of its recognized synonyms are examined, including information about the respective populations found across India and Sri Lanka. Our literature compilation and mapping analyses reveal three distinct populations - (I) Sri Lankan (probably also present in some parts of South India as well), (II) Peninsular Indian, and (III) Himalayan / Nepalese, separated by the Palk Strait and the Indo-Gangetic plains respectively.

Key words: Reed snake, Sri Lanka, India, population variation, synonyms, sexual dimorphism.

\section{Introduction}

The Calamaria Reed Snake, Liopeltis calamaria, was described by Günther (1858) as Cyclophis calamaria, based on two adult specimens collected from "Ceylon" (=Sri Lanka, catalogued as types: BMNH 1946.1.21.64 and 1946.1.5.60). Even though Günther (1858) used two specimens for the description he did not provide specific data for any one of them. Later,
Jan (1862) described, then (1865) illustrated a morphologically similar species, Homalosoma baliolum from an unknown locality. Günther (1864) later described another species, Cyclophis nasalis, also from an unknown locality, which he regarded as similar to his previous species. In the description he stated "This species agrees in almost every aspect with Cyclophis calamaria, but it may be readily 
distinguished by the presence of two preoculars...".

Boulenger (1890) nonetheless synonymized Homalosoma baliolum and Cyclophis nasalis with Liopeltis calamaria. Smith (1943) followed this decision, and though he did not examine the holotype (by monotypy) specimen of Homalosoma baliolum, he regarded it as a subjective synonym of Liopeltis calamaria and this scheme has been followed by later workers. Boulenger $(1890,1894)$ provided detailed meristic data for Liopeltis calamaria (as Ablabes calamaria), and reported its geographic range as Madras Presidency and Bombay (=Mumbai), India, aside from its type locality in Sri Lanka.

Wall (1921) described the variation of ventral and subcaudal counts within Sri Lankan populations, commenting that the snake found on that island is rather distinct from Indian populations. In contrast, Smith (1943) contended that the meristic character variation observed between Indian and Sri Lankan populations was due to sexual dimorphism rather than geographical variation.

Deraniyagala (1955) disagreed with Smith's suggestion, and following Wall's (1921) assumption, named a new subspecies Liopeltis calamaria indicus (sic) for the Indian population without designating a type specimen [only referred to the Indian specimens examined in Wall (1921)], and the name, Liopeltis calamaria calamaria remained with the Sri Lankan population. Subsequent authors have not accepted Deraniyagala's subspecific separation and have considered Liopeltis calamaria a rare but widely distributed monotypic species in Sri Lanka and India (De Silva 1969, 1980, de Silva 1990, Das 1994, Batuwita 2001, Somaweera 2006).

In much of the historical literature, Liopeltis calamaria is considered uncommon throughout its range (Willey 1906, Sarasin 1910, Cazaly 1914, Wall 1919, 1921). More recent work on Indian and Sri Lankan snakes (Daniel 2002, Das 2002, Das \& de Silva 2005, Whitaker \& Captain 2008) have not shed any further light on this species. Recently it has been observed in Sri Lanka (Karunarathna et al. 2004, Karunarathna \& Perera 2010). To provide more clarity on this taxon, we hereby illustrate and redescribe one of the two syntypes of Cyclophis calamaria and all other available types of all its subjective synonyms.

We also map its distribution in Sri Lanka and India based on published records, observed specimens, and museum collections.

\section{Material and methods}

Specimens were examined in the collections of the Natural History Museum, London UK (BMNH); Ecological Resource Monitoring Lab, Sri Sailam India (ERM); Madras Government Museum, India (MAD); Naturhistorisches Museum Wien, Vienna, Austria (NMW); Naturalis Biodiversity Center, Nationaal Natuurhistorische Museum (Rijksmuseum), Leiden, The Netherlands (RMNH); Vietnam National University, Hà Nội, Vietnam (VNUH); Zoological Research Museum Alexander Koenig, Bonn, Germany (ZFMK); Zoological Museum of Moscow University, Moscow, Russia (ZMMU); and Zoological Survey of India, Kolkata, India (ZSI). Museum acronyms follow Uetz et al. (2019). Morphometric and meristic data for species comparisons were obtained from examined specimens (see Appendix I). Natural history data were taken from our own field observation notes made during the last ten years, as well as published literature.

The following characters were measured with a digital caliper $( \pm 0.1 \mathrm{~mm})$ : eye diameter (ED, horizontal diameter of eye); eye-nostril length (distance between anterior most point of eye and middle of nostril); snout length (ES, distance between anterior most point of eye and snout); nostril diameter (horizontal diameter of nostril); internarial distance (least distance between nostrils); mandible-posterior eye distance (distance between posterior edge of mandible and posterior most edge of eye); interorbital width (IO, least distance between upper margins of orbits); head length (HL, distance between posterior edge of mandible and tip of snout); head width (HW, maximum width of head); snout-vent length (SVL, measured from tip of snout to anterior margin of vent); tail length (TL, measured from anterior margin of vent to tail tip). Meristic characters were taken as follows: supralabials and infralabials (first labial scale to last labial scale bordering gape); costal scales (counted around the body from one side of ventrals to the other in three positions, on one head length behind neck, at mid body and at one head length prior to anal plate); when counting the number of ventral scales, we scored specimens according to the method described by Dowling (1951). We counted subcaudal scales from first subcaudal scale to the scale before the tip of the tail. 


\section{Taxonomy}

\section{Liopeltis calamaria (Günther, 1858)}

(Figs. 1-4, 6; Tables 1, 2)

Cyclophis calmaria Günther, 1858

Homalosoma baliolum Jan, 1862

Cyclophis nasalis Günther, 1864

Cyclophia calamaria (sic) — Phipson 1888

Ablabes calamaria - Boulenger 1890

Liopeltis calamaria — Wall 1921, Smith 1943

Opheodrys calamaria - Constable 1949

L. calamaria indicus (sic) — Deraniyagala, 1955

Liopeltis calamaria indica Deraniyagala, 1955

Liopeltis calamarius (sic) — Wallach et al. 2014

Syntypes $(\boldsymbol{n}=2)$. BMNH 1946.1.5.60 (adult male) and BMNH 1946.1.21.64 (subadult male); collected from "Ceylon" (=Sri Lanka) by an unknown collector [according to the museum registry].

Other specimens $(\boldsymbol{n}=\mathbf{3 0})$. See Appendix I

Diagnosis. Liopeltis calamaria can be separated from its congeners by the following combination of morphological characters: 130-136 ventrals in males; 66-76 subcaudals in males; longer snout, ED $60.6-65.5 \%$ of ES; no loreal; single nasal shield; dorsal scales in 15-15-15 rows, all smooth; single preocular, 2 postoculars and $1+2$ temporals; 7 supralabials, of which $3^{\text {rd }}$ and $4^{\text {th }}$ in contact with the eye; 7 infralabials; nasal contacting internasal and prefrontal; prefrontal separated from supralabials by the preocular and the nasal; subcaudal scales paired, and dorsally light brown, greenish-brown or olive green coloration.

Redescription of syntypes. Meristic characters of the adult male syntype (BMNH 1946.1.5.60) are followed, where appropriate, by those of the subadult male syntype (BMNH 1946.1.21.64) in square brackets. Adult male [subadult male], SVL $227.0 \mathrm{~mm}$ [192.0 mm]; tail length 150.0 $\mathrm{mm}[85.0 \mathrm{~mm}]$; head elongate (HL $4.4 \%$ of SVL), twice as long as wide (HW $60.4 \%$ of HL), slightly flattened, distinct from neck; snout elongate (ES 37.6\% of HL), moderate, blunt in dorsal view, rounded in lateral profile, forming an oval shape, rather depressed.

Rostral shield large, hemispherical, distinctly visible from above, rounded posteriorly; interorbital width broad (IO 63.9\% of HW); internasals semicircular; nostrils rather small; nasals undivided, elongate, replacing the position of loreal, in anterior contact with rostral, internasal and prefrontal dorsally, $1^{\text {st }}$ and $2^{\text {nd }}$ supralabial ventrally; prefrontal rather large, broader than long, and subhexagonal; frontal large, subhexagonal, elongate posteriorly and longer than its width; supraoculars wide, elongated, subrectangular, posteriorly wider; parietals large, butterfly wing-like in shape, bordered by supraoculars, frontal, upper postocular anteriorly, anterior and upper posterior temporals, and five dorso-nuchal scales posteriorly; no loreal scale; one preocular (both sides), vertically elongated, hexagonal, in contact with prefrontal and nasal anteriorly, supraocular dorsally, and $2^{\text {nd }} \& 3^{\text {rd }}$ supralabial ventrally; eye large (ED 20.8\% of HL), round, nearly the same size as snout length (ED 50\% of ES), pupil rounded; two postoculars, upper postocular larger, pentagonal, in contact with supraocular, parietal and anterior temporal broad, in narrow contact with lower postocular; lower postocular crescent in contact with $4^{\text {th }}$ and $5^{\text {th }}$ supralabial ventrally, anterior temporal posteriorly; temporals $1+2$, elongated, hexagonal; anterior temporal larger and slightly longer than posterior temporals, in contact with parietal dorsally, $5^{\text {th }}$ and $6^{\text {th }}$ supralabial ventrally; posterior temporals smaller, lower one in contact with $6^{\text {th }}$ and $7^{\text {th }}$ supralabials ventrally.

Supralabials 7 (on both sides), $4^{\text {th }}-7^{\text {th }}$ larger in size, $6^{\text {th }}$ being the largest; $1^{\text {st }}$ supralabial in contact with rostral anteriorly, nasals dorsally, $2^{\text {nd }}$ supralabial with nasal and preocular dorsally, $3^{\text {rd }}$ supralabial with preocular and orbit dorsally, $4^{\text {th }}$ supralabial with orbit and the lower postocular dorsally, $5^{\text {th }}$ supralabial with lower postocular and anterior temporal dorsally, $6^{\text {th }}$ supralabial with anterior temporal and lower posterior temporal dorsally, and $7^{\text {th }}$ supralabial with lower posterior temporal dorsally and body scales posteriorly.

Mental of moderate size, triangular, wider than its length; first infralabial pair larger than mental plate and in broad contact with each other, in contact with anterior chin shield posteriorly; seven infralabials, $1^{\text {st }}-4^{\text {th }}$ in contact with first chin shield, $4^{\text {th }}$ infralabial largest in size in narrow contact with the anterior chin shield and in broader contact with the posterior chin shield; $5^{\text {th }}$ infralabial in narrow contact with posterior chin shield, $6^{\text {th }}-7^{\text {th }}$ infralabials in contact with gular scales; two larger anterior chin shields in broad contact, and two smaller posterior chin shields in narrow contact; posterior chin shields bordered posteriorly by five gular scales.

Body robust, elongate and subcylindrical; costal scales in 15-15-14 rows [15-15-15], all 
smooth and bluntly pointed; 130 ventral scales [134]; anal plate divided. Tail comparatively short (TL $66.1 \%$ of SVL), robust and thick; 76 [72] paired subcaudals.

Colouration. In preservation, dorsally yellowish chestnut brown; the dorsolateral scales (5-6 rows above the ventrals) edged with black colour, create two longitudinal lines on each side of the vertebral column; these lines break up rapidly into spots anteriorly and continues well onto the mid body and disappear towards the posterior body and tail; ventral side yellow [pale in colour; the black longitudinal line absent, instead dark brown patches break up into spots anteriorly; ventral side cream].

In life (based on live specimens, not collected), dorsally light brown, greenish-brown or olive green; the dorsal scales (5-6 rows above the ventrals) edged with black colour creating paired longitudinal lines on each side of the vertebral column, which break into spots anteriorly and continue well onto the tail; the area between these two lines is sometimes darker in colour; another less distinct line runs along the confines of the $3^{\text {rd }}-4^{\text {th }}$ rows; a series of black spots occur on each side of the head; ventral side pale yellow or cream. The black line is more prominent among juveniles than adults (Fig. 1); an ill-defined but distinct dark patch can be seen on the parietal region. Also, some juveniles exhibit lateral white linear stripes that begin on the neck and finish at the level of vent.

\section{Redescription of Liopeltis calamaria indica Deraniyagala, 1955}

L. calamaria indicus (sic) Deraniyagala, 1955

\section{Lectotype (designated herein). BMNH} 1922.5.25.22 (male); collected from Waynad (=Wayanad), Kerala, India, by Frank Wall [Registered on 25 May 1922 according to the museum registry]. See the discussion for details related to the syntype series.

Paralectotypes. ZSI 18608 (male); collected from Waynaad (=Wayanad), Nilgiris, Kerala, India, by Frank Wall. Note: The other paralectotypes most probably assorted with $L$. calamaria, and others might be lost, misplaced or destroyed.

Description of lectotype. Male, SVL $165.0 \mathrm{~mm}$; tail length $70.0 \mathrm{~mm}$; head elongate (HL $5.5 \%$ of SVL), twice as long as wide (HW $47.2 \%$ of HL), slightly flattened, distinct from neck; snout elongate (ES $28.6 \%$ of HL), moderate, blunt in dorsal view, rounded in lateral profile, forming an oval shape, rather depressed.

Rostral shield large, hemispherical, distinctly visible from above, rounded posteriorly; interorbital width broad (IO 65.1\% of HW); internasals semicircular; nostrils rather small; nasals undivided, elongate, replacing the position of loreal, in anterior contact with rostral, internasal and prefrontal dorsally, $1^{\text {st }}$ and $2^{\text {nd }}$ supralabial ventrally; prefrontal rather large, broader than long, and subhexagonal; frontal large, subhexagonal, elongate posteriorly and longer than its width; supraoculars wide, elongated, subrectangular, posteriorly wider; parietals large, butterfly wing-like in shape, bordered by supraoculars, frontal, upper postocular anteriorly, anterior and upper posterior temporals, and six dorso-nuchal scales posteriorly; no loreal scale; one preocular (both sides), vertically elongated, hexagonal, in contact with prefrontal and nasal anteriorly, supraocular dorsally, and $2^{\text {nd }} \& 3^{\text {rd }}$ supralabial ventrally; eye large (ED 19.8\% of HL), round, smaller than the size of snout length (ED 69.2\% of ES), pupil rounded; two postoculars, upper postocular larger, pentagonal, contact with supraocular, parietal and anterior temporal broad, in narrow contact with lower postocular; lower postocular crescent in contact with $4^{\text {th }}$ and $5^{\text {th }}$ supralabial ventrally, anterior temporal posteriorly; temporals 1+2, elongated, hexagonal; anterior temporal larger and slightly longer than posterior temporals, in contact with parietal dorsally, $5^{\text {th }}$ and $6^{\text {th }}$ supralabial ventrally; posterior temporals smaller, lower one in contact with $6^{\text {th }}$ and $7^{\text {th }}$ supralabials ventrally.

Supralabials 7 (on both sides), $4^{\text {th }}-7^{\text {th }}$ larger in size, $6^{\text {th }}$ being the largest; $1^{\text {st }}$ supralabial in contact with rostral anteriorly, nasals dorsally, $2^{\text {nd }}$ supralabial with nasal and preocular dorsally, $3^{\text {rd }}$ supralabial with preocular and orbit dorsally, $4^{\text {th }}$ supralabial with orbit and the lower postocular dorsally, $5^{\text {th }}$ supralabial with lower postocular and anterior temporal dorsally, $6^{\text {th }}$ supralabial with anterior temporal and lower posterior temporal dorsally, and $7^{\text {th }}$ supralabial with lower posterior temporal dorsally and body scales posteriorly.

Mental of moderate size, triangular, wider than length; first infralabial pair larger than mental plate and in broad contact with each other, in contact with anterior chin shield posteriorly; seven infralabials, $1^{\text {st }}-4^{\text {th }}$ in contact with first chin shield, $4^{\text {th }}$ infralabial largest in size in narrow contact with the anterior chin 


\section{Plate 15}
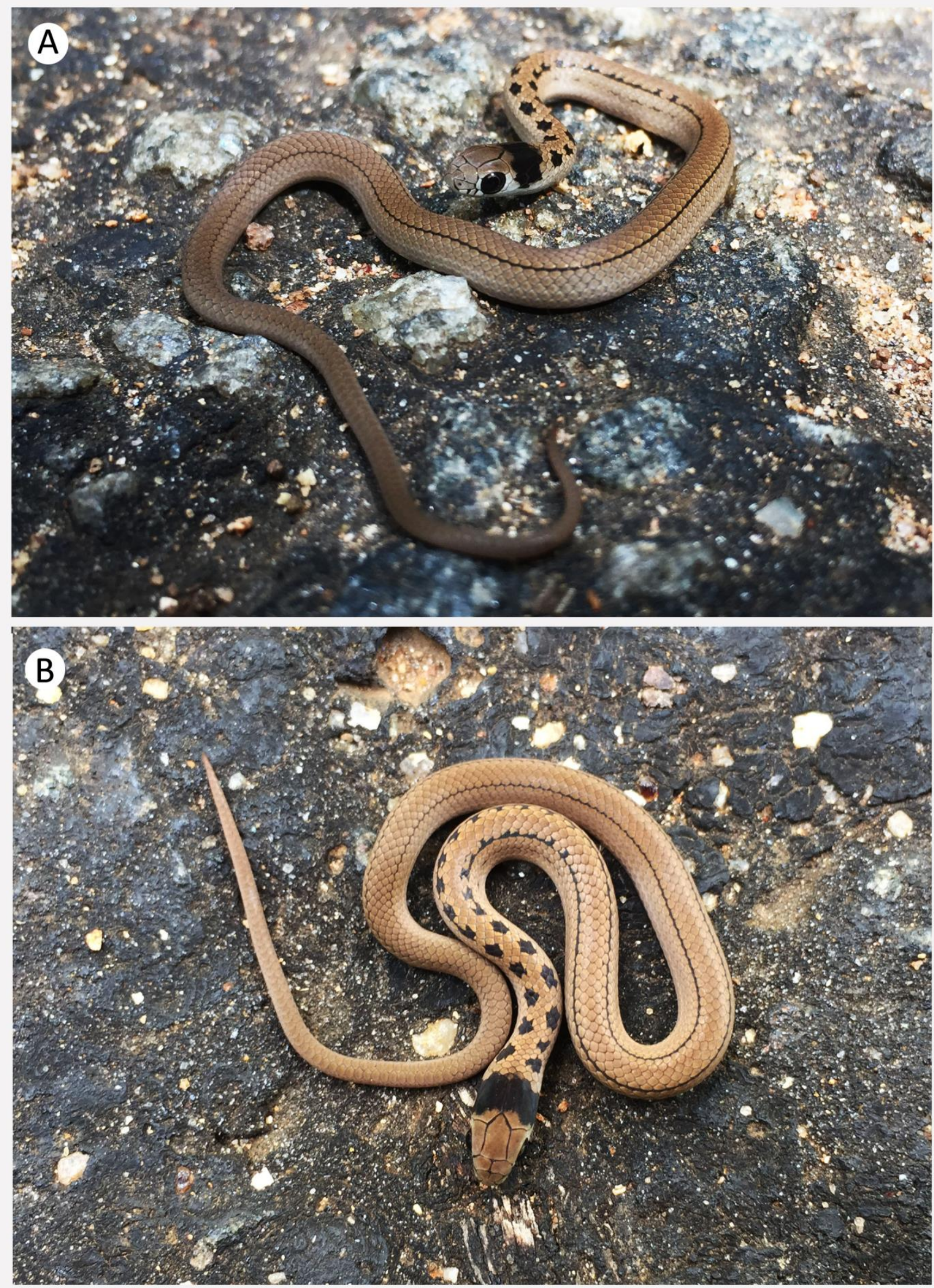

Figure 1. A juvenile of Liopeltis calamaria, (A) dorsolateral view, (B) dorsal view, observed at Duviliella Kaltota (Uva Province), Sri Lanka (not collected). Photographs (C) Dushmantha Kulathunga. 


\section{Plate 16}

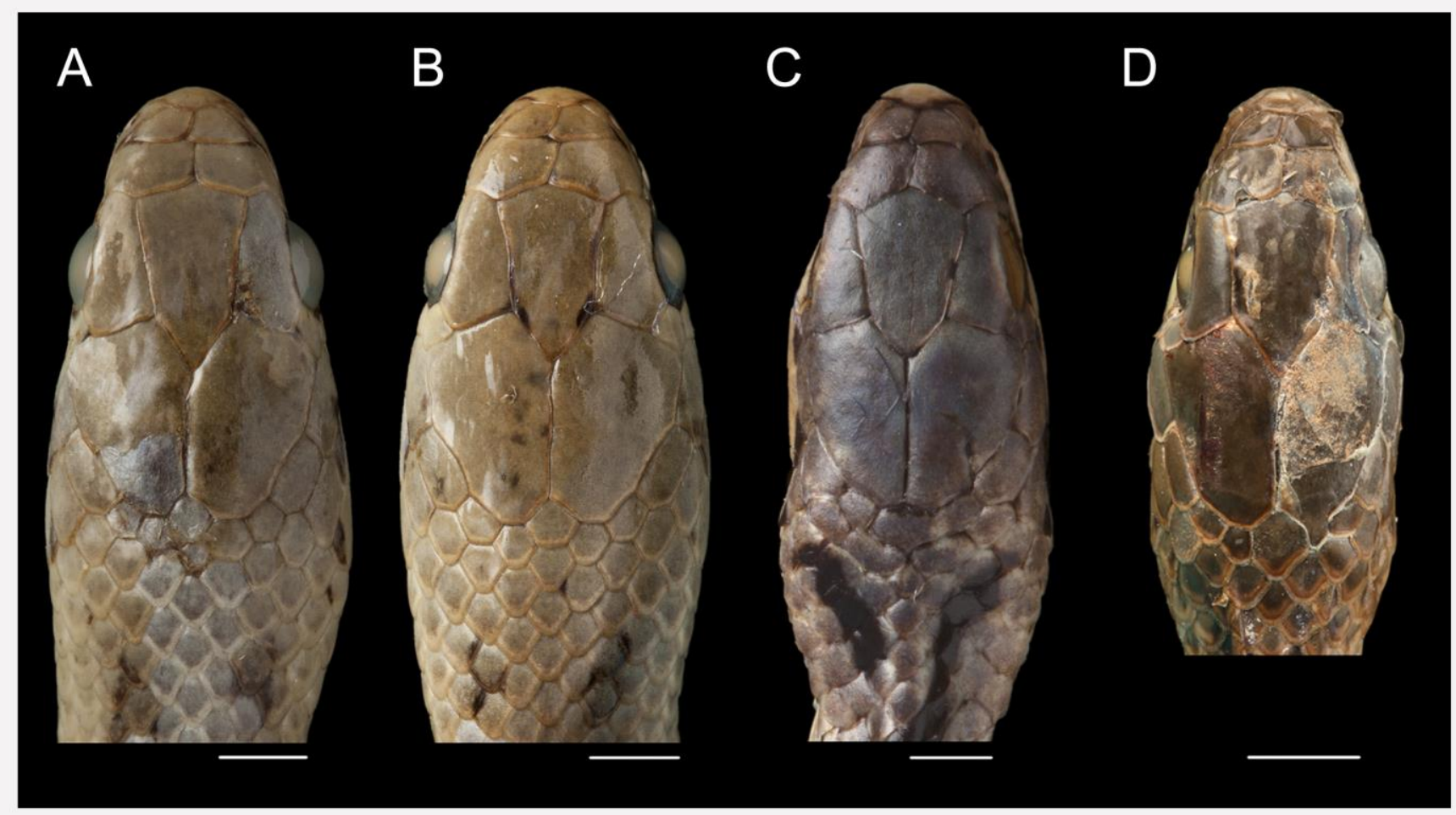

Figure 2. Dorsal head view of Liopeltis calamaria syntypes (A) BMNH 1946.1.5.60; (B) BMNH 1946.1.21. 64; (C) Cyclophis nasalis holotype BMNH 1946.1.5.36; and (D) Liopeltis calamaria indica lectotype BMNH 1922.5.25.22; scale: $2 \mathrm{~mm}$. (C) The Trustees of the Natural History Museum, London.

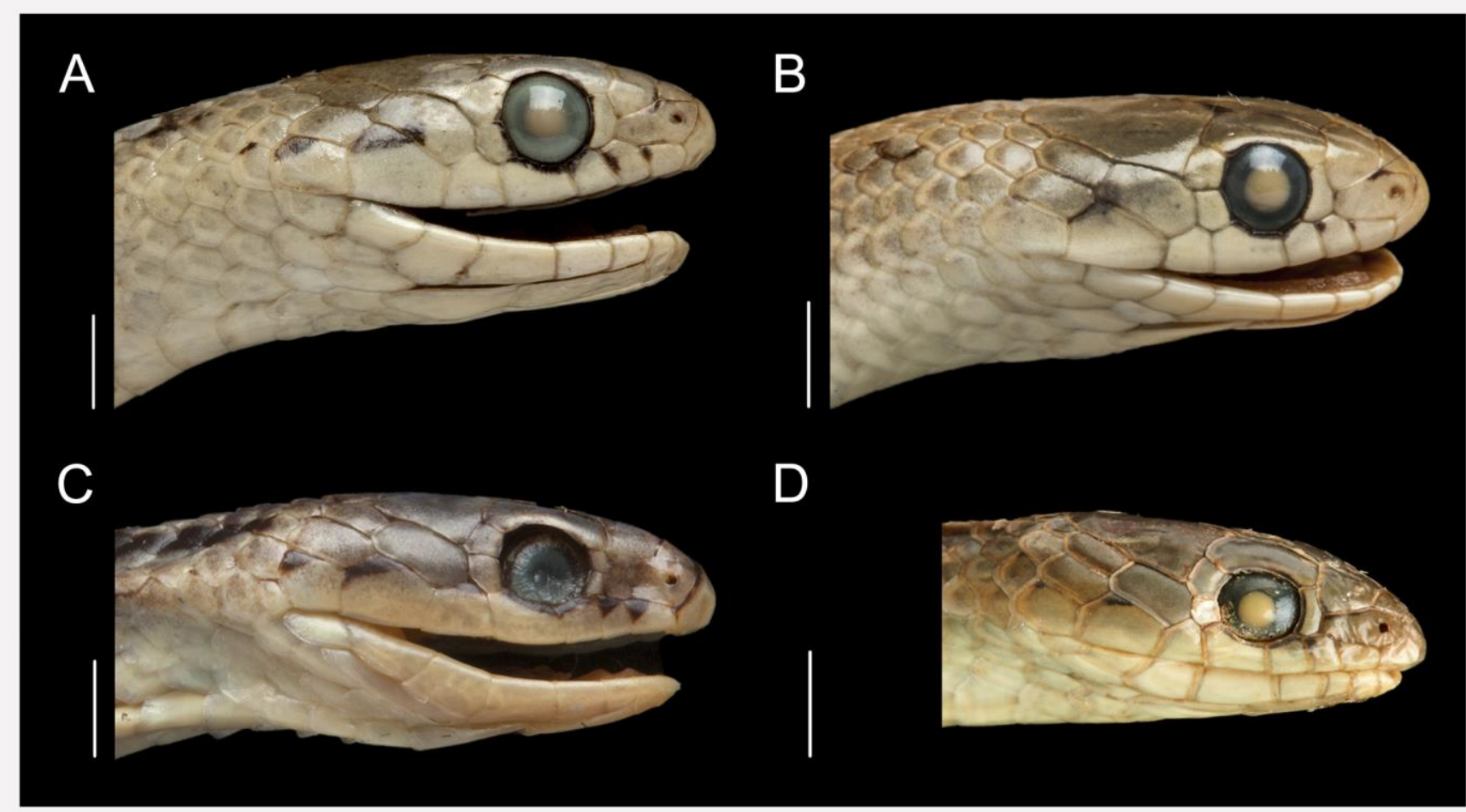

Figure 3. Lateral head view of Liopeltis calamaria syntypes (A) BMNH 1946.1.5.60; (B) BMNH 1946.1.21. 64; (C) Cyclophis nasalis holotype BMNH 1946.1.5.36; and (D) Liopeltis calamaria indica lectotype BMNH 1922.5.25.22; scale: $10 \mathrm{~mm}$. (C) The Trustees of the Natural History Museum, London. 
shield and in broader contact with the posterior chin shield; $5^{\text {th }}$ infralabial in narrow contact with posterior chin shield, $6^{\text {th }}-7^{\text {th }}$ infralabials in contact with gular scales; two larger anterior chin shields in broad contact, and two smaller posterior chin shields in narrow contact; posterior chin shields bordered posteriorly by six gular scales.

Body robust, elongate and sub-cylindrical; costal scales in 16-15-13 rows, all smooth and bluntly pointed; 126 ventral scales; anal plate divided. Tail comparatively short (TL $42.4 \%$ of SVL), robust and thick; 62 paired subcaudals.

Colouration. In preservation, dorsally yellowish chestnut brown; the dorsolateral scales (5-6 rows above the ventrals) edged with black colour creating two longitudinal lines on each side of the vertebral column, this line breaks up and disappears on the anterior part of the body; ventral side cream.

Dentition. Maxillary 24, Palatine 15, Pterygoid 16, Mandibular 18 teeth (Wall 1919).

Table 1. Morphometric (in mm) and meristric character comparisons of Liopeltis calamaria (Günther, 1858) syntypes; Liopeltis calamaria indica Deraniyagala, 1955 lectotype; Cyclophis nasalis Günther, 1864 holotype; and other examined specimens" _." = not measured/counted.

\begin{tabular}{|c|c|c|c|c|c|c|}
\hline \multirow[b]{2}{*}{ Character } & \multicolumn{3}{|c|}{ L. calamaria } & \multicolumn{2}{|c|}{ L. calamaria indica } & \multirow{2}{*}{$\begin{array}{c}\text { C. nasalis } \\
\text { Holotype } \\
\text { BMNH } \\
1946.1 .5 .36\end{array}$} \\
\hline & $\begin{array}{c}\text { Syntype } \\
\text { BMNH } \\
1946.1 .5 .60 \\
\end{array}$ & $\begin{array}{c}\text { Syntype } \\
\text { BMNH } \\
1946.1 .21 .64 \\
\end{array}$ & $\begin{array}{c}\text { Others } \\
n=4\end{array}$ & $\begin{array}{c}\text { Lectotype } \\
\text { BMNH } \\
\text { 1922.5.25.22 }\end{array}$ & $\begin{array}{c}\text { Others } \\
n=3\end{array}$ & \\
\hline Locality & \multicolumn{3}{|c|}{ Ceylon (Sri Lanka) } & \multicolumn{2}{|c|}{ Wayanad (India) } & Unknown \\
\hline snout-vent length (SVL) & 227.0 & 192.0 & $195.0-218.0$ & 165.0 & $150.0-335.0$ & 285.0 \\
\hline tail length (TAL) & 150.0 & 85.0 & $82.0-90.0$ & 70.0 & $55.0-90.0$ & 105.0 \\
\hline head length (HL) & 10.1 & 9.3 & $10.2-10.8$ & 9.1 & $10.5-12.5$ & 10.2 \\
\hline head width (HW) & 6.1 & 5.6 & $5.2-6.0$ & 4.3 & $5.5-9.0$ & 5.4 \\
\hline internarial distance & 2.3 & 2.2 & $2.3-2.5$ & 2.0 & $2.1-3.2$ & 2.4 \\
\hline interorbital width (IO) & 3.9 & 3.8 & $3.8-4.0$ & 2.8 & $2.5-5.2$ & 3.6 \\
\hline eye-nostril length & 2.2 & 1.8 & $1.9-2.2$ & 1.5 & $1.5-2.7$ & 1.9 \\
\hline eye-snout length (ES) & 3.8 & 3.0 & $2.9-3.1$ & 2.6 & $2.4-3.8$ & 2.9 \\
\hline mandible-eye distance & 5.5 & 4.9 & $3.9-4.1$ & 5.6 & 5.5 & 5.4 \\
\hline nostril diameter & 0.4 & 0.4 & 0.4 & 0.2 & 0.4 & 0.3 \\
\hline eye diameter (ED) & 2.1 & 1.8 & 1.9 & 1.8 & $1.9-2.3$ & 2.2 \\
\hline costals & $15,15,14$ & $15,15,15$ & $15,15,15$ & $16,15,13$ & $15,15,15$ & $15,15,15$ \\
\hline subcaudals & 76 & 72 & $66-70$ & 62 & $59-73$ & 72 \\
\hline ventrals & 130 & 134 & $131-135$ & 126 & $121-158$ & 151 \\
\hline supralabials & 7 & 7 & 7,8 & 7 & 6,7 & 7 \\
\hline infralabials & 7 & 7 & 7 & 7 & 6,7 & 7 \\
\hline
\end{tabular}

The following data was published in previous literature for Liopeltis calamaria sensu lato.

Variation. See Tables 1 and 2.

Hemipenis. The hemipenis of Liopeltis calamaria extends to the $10^{\text {th }}$ caudal plate; distal half calyculate; calyces smaller, deeply scalloped, closely packed, only the papillae are visible on the surface; the spines in the spinous region are shorter, thicker and numerous (De Silva 1980); a fold is present (Smith 1943).

Dentition. Maxillary 24-26, Palatine 15-16, Pterygoid 15-16, Mandibular 18-21 teeth (Wall 1919, 1921, Smith 1943).

Natural history. A terrestrial, diurnal snake usually preferring dry mixed deciduous habitats near water bodies, and also mostly found underneath rotten $\operatorname{logs}$ on the forest floor covered with a thick layer of leaf litter. Notably, found frequently near the forest edge and rarely inside the forest itself or in deep forest. It appears to be a highly-adaptable species found between low-lying coastal scrub belts such as Puttalam Bay and the adjacent Wilpattu coast to tall mountainous sub-Alpine forest tracts such as Kullu Manali in Himalaya and the montane sholas of the Kannan Devan Hills of the Western Ghats. This species is insectivorous, having a preferred diet of smooth-bodied caterpillars, crickets, grasshoppers and spiders (Ditmars 1910). It is known to be oviparous (Deoras 1965). It does not try to bite when disturbed and prefers to hide or escape. When defending, it puffs up the anterior portion of the body to display the darker interstitial skin in the neck region (Karunarthna \& Perera 2010). Natural predators are assumed to be ophiophagous birds such as crested serpent eagles (Spilornis cheela), shikras (Accipiter badius), white-breasted king 
fishers (Halcyon smyrnensis), and grey hornbills (Ocyceros gingalensis). It is known to inhabit mainly mountainous tracts including low $(<300$ $\mathrm{m}$ see Karunarathna et al. 2004, Karunarathna \& Perera 2010, Ganesh et al. 2018), mid (900 m see Chikane \& Bhosale 2012) and high elevations (1600-2,000 m, see Ferguson 1902, Wall 1919, Malhotra \& Davis 1991).

Distribution. Even though Liopeltis calamaria is considered a widely distributed species throughout Sri Lanka and India (Somaweera 2006, Whitaker \& Captain 2008, Smith 1943), it is also considered to be rare in both countries, which are separated by the $32 \mathrm{~km}$ wide Palk Strait (see Ferguson 1877, Wall 1919, 1921). Wall (1921) and Taylor (1950) did not examine any specimens from Sri Lanka.

In Sri Lanka: Subsequent to its original description by Günther in 1858, Deraniyagala (1955) recorded this subspecies from Badulla, Uva patanas, Haputale (Uva Province), Varahena (Southern Province), Marai Vila (=Marawila, North-western Province), Sigiri (=Sigiriya, North-central Province). De Silva (1990) reported one specimen from Opatha (Southern Province) and Batuwita (2001) found one from Kottawa (Southern Province). The latter author further recorded two specimens present at National Museum of Sri Lanka (NMSL), which had been collected from Periyankulam (Madu Road) and Polonnaruwa (North Central Province). Karunarathna et al. (2004) observed this species at Kukulugala (Sabaragamuwa Province) and Ritigala (Northcentral Province). Later, Karunarathna \& Perera (2010) and Karunarathna \& Amarasinghe (2010) recorded it from Nilgala (Uva Province) and Eluwankulama (Northwestern Province). We additionally observed $L$. calamaria at PaalaviyaPuttalam (Northwestern Province), DuviliellaKaltota (Uva Province), Wasgomuwa (Northcentral Province), Udawalawa (Uva Province), and Minneriya (North-central Province). Since its original description in 1858 (over 160 years ago), this species has been sighted approximately only 20 times, indicating that it is one of the rarest snakes in Sri Lanka (see Fig. 4 for current distribution records of this species).

In India: Beddome (1863) was perhaps the first to record this species from this country when he reported one specimen from the Shevaroy Hills in the Eastern Ghats. $\mathrm{He}$ explicitly states that he had recorded the species which Günther had described from Ceylon (=Sri Lanka). Subsequent treatises state its distribution in India to be "peninsular India" (Günther 1864), "South India" (Theobald 1876) and "Madras Presidency, Bombay" (Boulenger 1890). Phipson (1888) reports specimens from Ceylon and Mahabaleshwar (in Western Ghats) housed in the Bombay Natural History Society Museum. Sclater (1891) lists specimens from Sirgaja, Chota Nagpur and from Tinnevelley (ZSI 4421), Madras Presidency (ZSI 8734 and 8735; both coll. by R.H. Beddome). Boulenger (1894) examined one additional specimen from Sri Lanka and five specimens from India: Kotagiri Nilgherries, Sevagherry Ghat, Madras Presidency, and Matharan, all localities in the Western Ghats. Ferguson (1902) reports of having observed one atop the Kannan Devan Hills, near Munnar in the wet, montane regions of the Southern Western Ghats. Wall (1919) mentions it as being "evidently an uncommon snake", he reports it from Wynad and remarks that its scalation matches Boulenger's description well. Until this period, the species had been known only from Sri Lanka and the peninsula of India. But soon afterwards, records from the Himalayan region started to emerge. Wall (1921) did not observe any specimen from Sri Lanka, but reported Indian specimens from Mahableshwar, Wynaad, Nilgiris, and Bangalore. Later he (Wall 1924) mentions this species from Buxa Dooras, Songara of Gond District, Khurkhana in Philibit District, Melanghat in Almorah District (all in the far North of India), Surguja in Chota Nagpur District, Mahabaleshwar, Mysore plateau and Tinnevelley Hills. Mullan (1927) recorded it from Panchgani in the Satara ranges of the Western Ghats. Smith (1943) stated the distribution to be "Western Ghats, as far north as Matheran, Tinnevelley Hills, Mysore Plateau, Bangalore, United Provinces, Chota Nagpur" while Whitaker (1978) located it from "Hilly areas throughout India, except extreme northwest". Constable (1949) reported one male and two females collected by R.H. Beddome from 'near Madras' lodged at the Museum of Comparative Zoology, Harvard, USA. Very few recent workers have reported the species from India. Malhotra \& Davis (1991) report sighting of three specimens in rock piles situated within the montane grasslands atop the Srivilliputhur Hills, at 1290-1690 m. Recent reports originated from Nallamalai Hills in Andhra Pradesh (Rao et al. 2005), Kambakkam Hills in Andhra Pradesh (Ganesh \& Asokan 2010), Kaas plateau in Maharashtra (Chikane \& Bhosale 2012), 


\section{Plate 17}

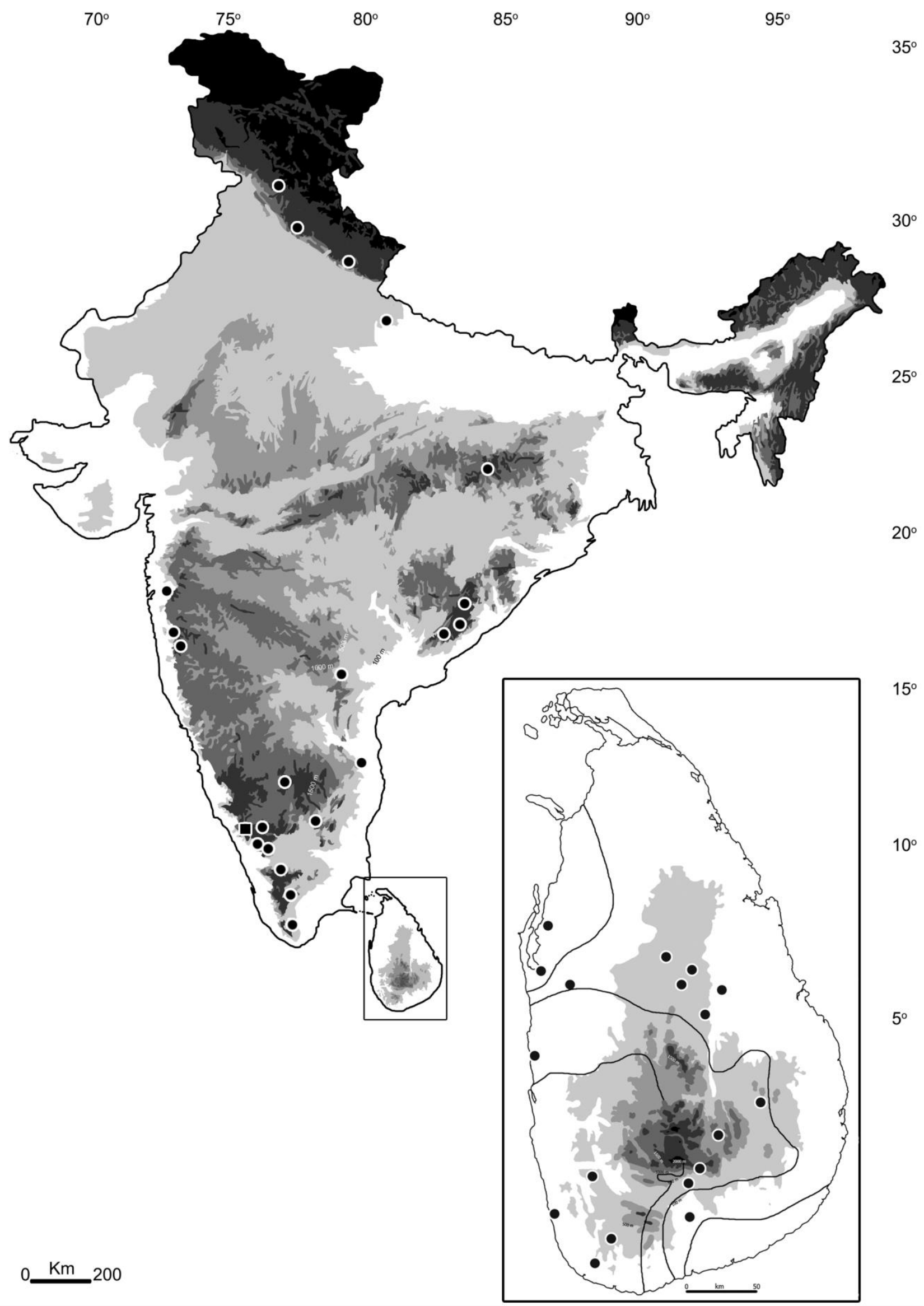

Figure 4. Distribution map of Liopeltis calamaria in Sri Lanka and India (circles) based on examined material and published literature. The exact location of the type locality of $L$. calamaria in Sri Lanka is unknown. The lectotype locality of $L$. c. indica is marked with a square symbol. 
Meghamalai Hills in Tamil Nadu (Bhupathy \& Sathishkumar 2013), Kalakadu Mundanthurai Tiger Reserve in Tamil Nadu (Narayanan 2016), and Vellore as well as the Gingee Hills of the Eastern Ghats in Tamil Nadu (Ganesh et al. 2018). Bhattarai et al. (2018) also reported the species from Nepal (Chitwan, Makwanpur). We suggest a careful study of those specimens and the adjoining Himalayan population (also see Wall 1924) that are fully geographically separated from the Peninsular Indian population by the mighty Indo-Gangetic plains (see Fig. 4).

Threats and Conservation. This species is found mostly in habitats where forest fires are a distinct threat, so is exposed to illegal logging and chena cultivation (shifting cultivation).
Clearing for agriculture, expanding human settlements, direct persecution by humans, because of mythical beliefs are some other common threats to this snake. In some habitats (e.g. Eluwankulama, Sri Lanka) mining for cement is identified as a threat (Karunarathna \& Perera 2010). The specimens recorded from Minneriya and Nilgala (Sri Lanka) were road kills, which is another threat to the species. In India this species has also been reported as road kills (Ganesh et al. 2018) and had featured in snake rescue data of animals affected by urbanisation (Nande \& Deshmukh 2007). In Nepal, this species has been reported to suffer from wanton killing out of fear by locals (Bhattarai et al. 2018).

Table 2. Ventral and subcaudal scale count comparisons between Sri Lankan and Indian populations of Liopeltis calamaria based on published literature and new data (this study): SL, Sri Lanka; IN, India; “_"“ Not applicable.

\begin{tabular}{|c|c|c|c|c|c|c|c|c|}
\hline \multirow{3}{*}{ Source } & \multicolumn{4}{|c|}{ Ventrals } & \multicolumn{4}{|c|}{ Subcaudals } \\
\hline & \multicolumn{2}{|c|}{ Males } & \multicolumn{2}{|c|}{ Females } & \multicolumn{2}{|c|}{ Males } & \multicolumn{2}{|c|}{ Females } \\
\hline & SL & IN & SL & IN & SL & IN & SL & IN \\
\hline $\begin{array}{l}\text { Günther (1858) syntypes } \\
(n=2)\end{array}$ & 129,134 & - & - & - & 72,76 & - & - & - \\
\hline Boulenger (1894) $(n=6)$ & 134 & - & - & $130-154$ & 68 & - & - & $64-70$ \\
\hline Wall (1919) $(n=5)$ & - & $126-132$ & - & $135-139$ & - & $59-70$ & - & $53-57$ \\
\hline Constable (1949) $(n=3)$ & - & - & - & $133-146$ & - & - & - & $60-71$ \\
\hline De Silva (1969) $(n=6)$ & $129-132$ & - & 134,139 & - & $65-73$ & - & 61,64 & - \\
\hline Batuwita (2001) $(n=1)$ & 133 & - & - & - & - & - & - & - \\
\hline $\begin{array}{l}\text { Karunarathna et al. } \\
(2004)(n=2)\end{array}$ & - & - & 148,156 & - & - & - & 52,58 & - \\
\hline $\begin{array}{l}\text { Karunarathna \& Perera } \\
(2010)(n=2)\end{array}$ & - & - & 159,162 & - & - & - & 61,65 & - \\
\hline This study $(n=7)$ & - & $121-136$ & - & 140,158 & - & $60-73$ & - & $65-73$ \\
\hline Summary & 129-134 & $121-136$ & $134-162$ & $130-158$ & $65-76$ & $59-73$ & $52-65$ & $53-73$ \\
\hline
\end{tabular}

\section{Discussion}

Phipson (1888) misspelt the generic name in his work, as Cyclophia. Constable (1949) challenged Smith's generic allocation and represented this species as Opheodrys calamaria, remarking that he follows most American herpetologists in considering Liopeltis a synonym of the unrelated, Nearctic genus Opheodrys Fitzinger, 1843. Wallach et al. (2014) changed the widely used Latin species epithet "calamaria" which is feminine in gender, to "calamarius" which is masculine in gender.

The generic name Liopeltis Fitzinger, 1843 is feminine, meaning "having smooth shields". It is derived from the Ancient Greek "pélte”", which means a small crescent-shaped shield (peltis in plural) and "leióō", which means smooth. Thus, the specific epithet calamaria is correctly placed, which also is feminine in the nominative case (originated from calamarius), derived from the Greek word "kalamos", meaning "tube, reed". Therefore, according to the Article 31.2 of the International Code of Zoological Nomenclature (ICZN 1999), we refute the amended epithet "calamarius" used by Wallach et al. (2014), and reinstate the correctly used previous species epithet "calamaria" as the current nomenclatural combination of this taxon. At the same time the subspecific epithet given by Deraniyagala (1955), is also corrected herewith as Liopeltis calamaria indica (not indicus) following the same article of the ICZN.

Günther's (1864) assignment of Liopeltis nasalis from an unknown locality (probably 
from India) is based on a similar diagnosis of having 149 ventrals and 77 subcaudals. Therefore, we presume that Günther's nomen $C$. nasalis as available for the Indian population even though the locality is stated as unknown. The morphological and meristic characters of the holotype of $C$. nasalis, however, fit within $L$. calamaria, we hence hereby follow Boulenger's view that $C$. nasalis is a junior subjective synonym of $L$. calamaria. The attempt to trace the type specimen of Jan's $(1862,1865)$ description of Homalosoma baliolum was unsuccessful. According to the curator of the collection it is missing, misplaced or has been destroyed (Pers. comm. Stefano Scali, Museo Civico di Storia Naturale di Milano, Italy; and Richard Gemel, Naturhistorisches Museum Wien, Vienna, Austria). However, based on the description of Jan (1862) it has 159 ventrals and 67 subcaudals (most probably a female specimen) and thus sits within the range known for this species [see Fig. 5 of this publication for the illustration in Jan (1865) respectively], but probably represents an unidentified population either from Sri Lanka or India. At this time, we therefore consider it a junior subjective synonym of $L$. calamaria, thus supporting the view of Boulenger (1890).

De Silva (1969) stated that this species shows slight sexual dimorphism. Deraniyagala (1955) assigned Indian population to the name Liopeltis calamaria indicus (sic) based on 126163 ventrals and 53-76 subcaudals (vs 121-138 ventrals and 61-76 subcaudals in the Sri Lankan population). In Table 1 and 2, for both sexes, we show that the Sri Lankan population has a minimum of 130 ventrals (6 specimens examined +11 specimens from literature), and Indian populations have a minimum of 134 ventrals (20 specimens examined). Even though neither a type specimen nor a series of syntypes for $L$. c. indica has been formally designated, Deraniyagala (1955) clearly referred to the specimens examined by Wall, stating the following “...ventrals 121 to 138 in Ceylon specimens, and 126 to 163 in Indian ones (Wall),...". Therefore, according to the Article 72.1 .1 , in the absence of a type designation, we consider all the specimens from India available to Wall $(1919,1921,1924)$ as type specimens, hence a type-series (syntypes). Wall (1921) stated that he had seen several examples including specimens from Mahableshwar, Wynaad, Nilgiris, and Bangalore, so there must have been in his possession at least four specimens. That being said, and unfortunately, we were able to locate only two among them (BMNH 1922.5.25.22 and ZSI 18608), which were both collected from Wynaad, India by Frank Wall himself. Furthermore, the ventral counts of those specimens are 126 and 121 respectively. Therefore, we regard BMNH 1922.5.25.22 as one of Wall's specimens stated by Deraniyagala (syntypes, 126-163 ventrals), and furthermore designate it as the lectotype of Liopeltis calamaria indica, in order to stabilize the subspecific name with a name bearing type specimen (onomatophore).

Interestingly the lectotype of $L$. c. indica, along with the paralectotype (ZSI 18608) also collected from Nilgiri-Wynad, is on the lower margin of ventral counts 121 and 126 ( $v s$ 130134) and subcaudal counts 59 and 62 (vs 68-76) compared to the Sri Lankan specimens (see Table 1). Also, if such a non-overlapping scalation range holds true for a larger series of specimens, the subspecies $L$. $C$. indica will turn out to be endemic to Western Ghats (probably around the area of Wayanad), while the formatypica L. c. calamaria would refer to the population in Sri Lanka (and perhaps some parts of South India). However, there might be several, more cryptic, species isolated in narrow ranges, especially in the Indian region. Specifically, we suggest a careful study of the Himalayan / Nepalese population (also see Wall 1924) that are fully separated from the Peninsular Indian population by the mighty zoogeographical barrier of the Indo-Gangetic plains, where there are no records to date. Molecular data from different populations all over the geographic range of this 'species' are required to further understand its evolutionary history and dispersal route, and this might also give evidence for raising the status from either synonyms or subspecies to a full species level.

\section{Acknowledgments}

We thank the former Director, K. Venkataraman (ZSI) for granting research permission. In particular we thank K. Chandra (Director) K. C. Gopi (officer-in-charge, FPS Building, ZSI, Kolkata), K. A. Subramanian (officer-in-charge, Technical Section, ZSI) for their help throughout the permitting application process. K. Deuti, S. Raha, P.G.S. Sethy, P. Bag, and S. Debnath are also acknowledged for assisting us while examining collections in ZSI. Silke Schweiger and Georg Gassner (NMW) gave us the opportunity for examining specimens under their 


\section{Plate 18}

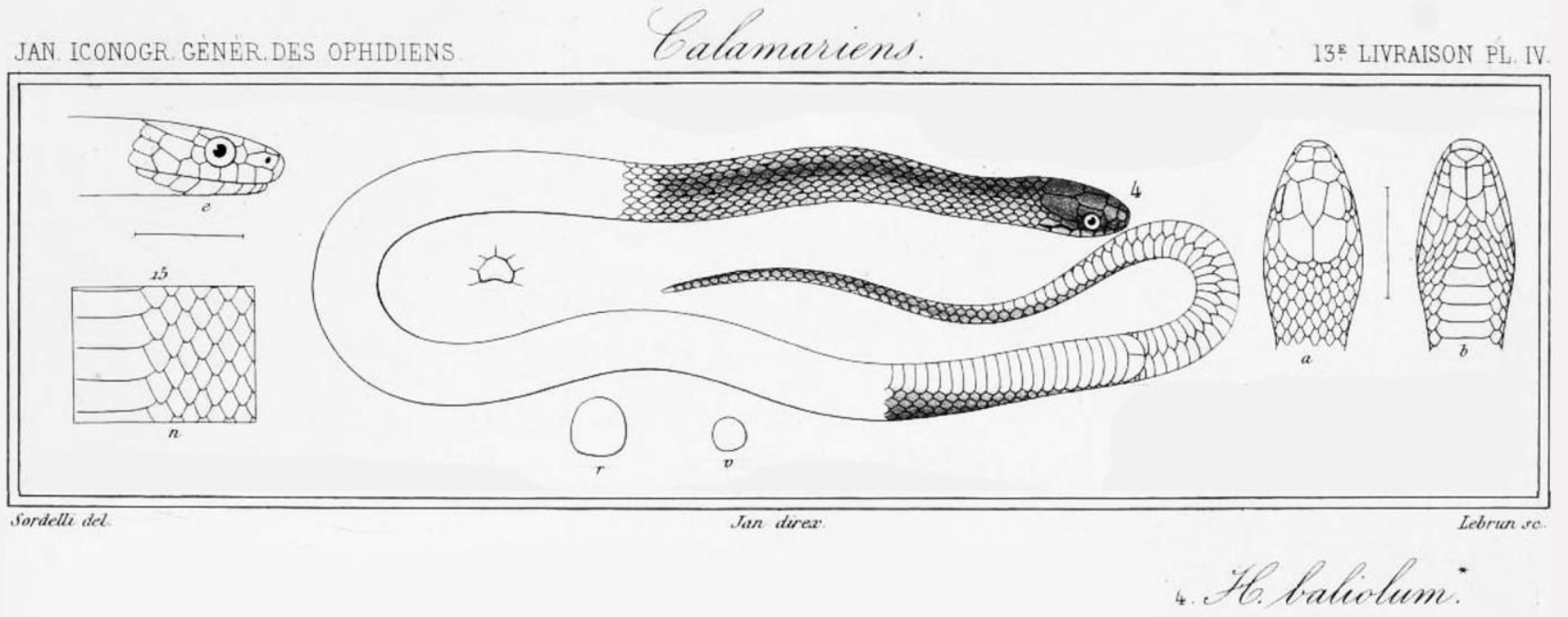

Figure 5. The original figure of Homalosoma baliolum illustrated by Jan; resized and reprinted from Jan, 1865 (Iconographie générale des ophidiens. 13, Bailière et Fils, Paris, Pl. IV).

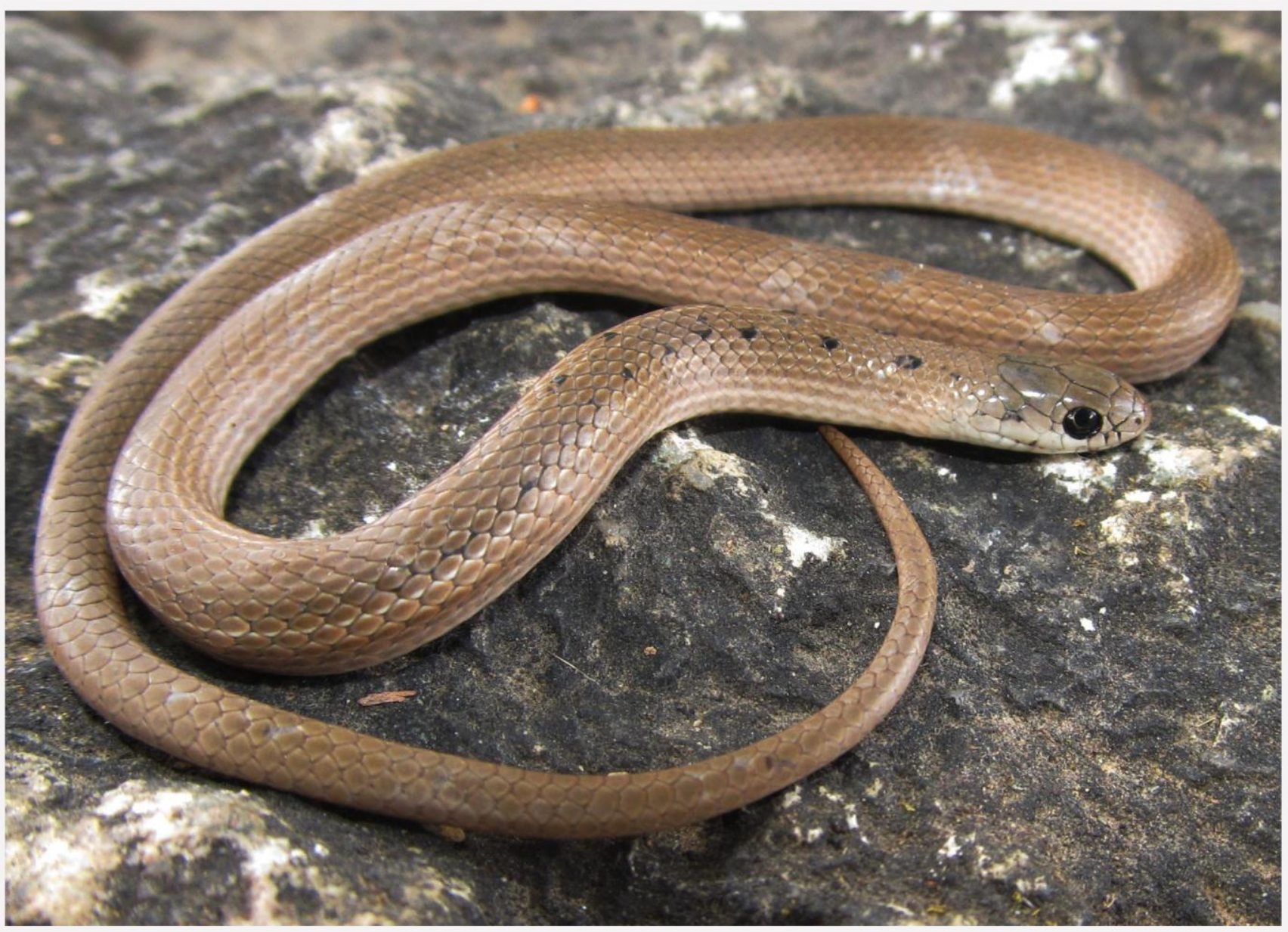

Figure 6. An adult of Liopeltis calamaria, observed at Vellore, Tamil Nadu State, India (not collected). Photograph (C) S. R. Ganesh. 
care. Dushmantha Kulathunga is acknowledged for photographs. SK thanks P. Antony, K. Gunawardena and V. Weeratunga for the travel grant to visit ZSI (India). SRG thanks the Executive Chairman and Trustees of Chennai Snake Park Trust for encouraging his research activities; and the Field Director NSTR, the Principal Commissioner, and the Secretary Madras Government Museum are also acknowledged for access to material under their care. Ivan Ineich (Muséum national d'Histoire naturelle), Philip Bowles (IUCN), and two anonymous reviewers are acknowledged for valuable comments and reviewing the manuscript. Finally, we thank J. Supriatna and the staff of the Research Center for Climate Change, University of Indonesia; and Anslem de Silva for their support.

\section{Literature cited}

Batuwita, S. (2001). Liopeltis calamaria (Günther, 1858) (Serpentes: Colubridae) first record from the Galle District, Southern Sri Lanka. Loris, 22 (6): 11.

Beddome, R.H. (1863). Further notes upon the snakes of the Madras Presidency; with descriptions of new species. Madras Quarterly Journal of Medical Science, 6: 41-48.

Bhattarai, S., C.P. Pokheral, and N. Subedi (2018). New Locality Record of the Lined Stripe necked Snake, Liopeltis calamaria (Günther, 1856) (Squamata: Colubridae) from Nepal. IRCF Reptiles \& Amphibians, 25: 125-126.

Bhupathy, S. and N. Sathishkumar (2013). Status of reptiles in Meghamalai and its environs, Western Ghats, Tamil Nadu, India. Journal of Threatened Taxa, 5 (15): 4953-4961.

Boulenger, G.A. (1890). The Fauna of British India, Including Ceylon \& Burma. Reptilia \& Batrachia. Taylor \& Francis, London: 541 pp.

Boulenger, G.A. (1894). Catalogue of the Snakes in the British Museum (Natural History). Volume II, Containing the Conclusion of the Colubrida Aglyphar. British Museum of Natural History, London: 382 pp.

Cazaly, W.H. (1914). The common snakes of India and Burma and how to recognize them. Pioneer Press, Allahabad: $60 \mathrm{pp}$.

Chikane, S. and H.S. Bhosale (2012). Reptiles of Kaas, Northern Western Ghats, Maharashtra, India, with notes on habitat preferences, abundances and threats. Sauria, 34 (3): 3-15.

Constable, J.D. (1949). Reptiles from the Indian Peninsula in the Museum of Comparative Zoology. Bulletin of the Museum of Comparative Zoology, 103 (2): 59-160.
Daniel, J.C. (2002). The book of Indian reptiles and amphibians. Bombay Natural History Society, Oxford Publishers, Mumbai: 238 pp.

Das, I. (1994). The reptiles of South Asia: checklist and distributional summary. Hamadryad, 19: 15-40.

Das, I. (2002). A photographic guide to snakes and other reptiles of India. New Holland, London: $144 \mathrm{pp}$.

Das, I. and A. de Silva (2005). A photographic guide to snakes and other reptiles of Sri Lanka. New Holland, London: 144 pp.

Deoras, P.J. (1965). Snakes of India. National Book Trust, New Delhi: 148 pp.

Deraniyagala, P.E.P. (1955). A Colored Atlas of Some Vertebrates from Ceylon. Volume 3 (Serpentoid Reptilia). Colombo National Museums, Sri Lanka: 200 pp.

de Silva, A. (1990). Colour Guide to the snake fauna of Sri Lanka. Avon, R \& A Publishers Ltd., Avon, London: 130 pp.

De Silva, P.H.D.H (1969). Taxonomic Studies on Ceylon Snakes of the Family Colubridae. Spolia Zeylanica, 31 (2): 431-546.

De Silva, P.H.D.H. (1980). Snakes Fauna of Sri Lanka, with special reference to skull, dentition and venom in snakes. Sri Lanka National Museums, Colombo: $472 \mathrm{pp}$.

Ditmars, R.L. (1910). Reptiles of the World. Sir Isaac Pitman \& Sons Ltd., London: 373 pp.

Dowling, H.G. (1951). A proposed standard system of counting ventrals in snakes. British Journal of Herpetology, 1 (5): 97-98.

Ferguson, W.M. (1877). Reptile Fauna of Ceylon. Letter on a collection sent to the Colombo Museum. Government Press, Colombo: 42 pp.

Ferguson, H.S. (1902). Travancore snakes. Journal of the Bombay Natural History Society, 14 (2): 386-387.

Ganesh, S.R. and J.R. Asokan (2010). Catalogue of Indian herpetological specimens in the collection of the Government Museum Chennai, India. Hamadryad, 35 (1): 46-63.

Ganesh, S.R., A. Kalaimani, P. Karthik, N. Baskaran, R. Nagarajan et al. (2018). Herpetofauna of Southern Eastern Ghats, India - II; from Western Ghats to Coromandel Coast. Asian Journal of Conservation Biology, 7 (1): 28-45.

Günther, A.C.L.G. (1858). Catalogue of Colubrine snakes of the British Museum. British Museum (Natural History), London: $281 \mathrm{pp}$.

Günther, A.C.L.G. (1864). The Reptiles of British India. Taylor \& Francis, London: 550 pp.

ICZN (1999). International Code of Zoological Nomenclature, $4^{\text {th }}$ edition. International Trust for Zoological Nomenclature, London: 306 pp. 
Jan, G. (1862). Enumerazione Sistematica delle specie d'ofidi Del Gruppo Calamaridae. Direttore del Civico Museo di Storia Naturale di Milano: $76 \mathrm{pp}$.

Jan, G. (1865). Iconographie générale des ophidiens. 13. Livraison. [Homalosoma mite]. J.B. Bailière et Fils, Paris: Plate IV.

Karunarathna, D.M.S.S. and A.A.T. Amarasinghe (2010). Reptile diversity of a fragmented lowland rain forest patch in Kukulugala, Ratnapura District, Sri Lanka. Taprobanica, 2 (2): 86-94.

Karunarthna, D.M.S.S. and W.P.N. Perera (2010). New Distribution Records for Liopeltis calamaria (Günther, 1858) (Reptilia: Serpentes: Colubridae), with Notes on its Bioecology and Threats in Sri Lanka. [in German]. Sauria, 32 (2): 49-55.

Karunarathna, D.M.S.S., D.H.P.U. Silva, H.T.A.P. Peiris, M.D.C. Asela, U.T.I. Abeywardena et al. (2004). Two new sightings of Liopeltis calamaria. Loris, 23 (5-6): 23-26.

Malhotra, A. and K. Davis (1991). A report on the herpetological survey of the Srivilliputhur Reserve Forests, Tamil Nadu. Journal of the Bombay Natural History Society, 88: 157-166.

Mullan, J.P. (1927). A list of snakes and lizards from Panchgani. Journal of the Bombay Natural History Society, 32 (2): 380-381.

Nande, R. and S. Deshmukh (2007). Snakes of Amravati District including Melghat, Maharashtra, with important records of the Indian egg-eater, montane trinket snake and Indian smooth snake. Zoos' Print Journal, 22 (12): 2920-2924.

Narayanan, S. (2016). On the occurrence of the Calamaria Reed Snake Liopeltis calamaria (Günther, 1858) (Squamata: Colubridae), in the Kalakadu Mundanthurai Tiger Reserve, India. Reptile RAP, 18: 29-30.

Palot, M.J. (2015). A checklist of reptiles of Kerala, India. Journal of Threatened Taxa, 7 (13): 8010-8022.

Phipson, H.M. (1888). Catalogue of snakes in the society's collection. Journal of the Bombay Natural History Society, 3 (1): 49-53.

Rao, K.T., H.V. Ghate, A.M. Sudhakar, S.M Javed, and I.S.R Krishna (2005). Herpetofauna of Nallamalai Hills with eleven new records for the region including ten new records for Andhra Pradesh. Zoos' Print Journal, 20 (1): 1737-1740.
Sarasin, F. (1910). Über die Geschichte der Tierwelt von Ceylon. In: Spengel, J.W. (ed.), Zoologische Jahrbücher [in German], Germany, Sup. 12: 754 pp.

Sclater, W.L. (1891). Notes on a collection of snakes in the Indian Museum, with descriptions of several new species. Journal of the Asiatic Society of Bengal, LX: 230-250.

Sharma, R.C. (2004). Handbook of Indian Snakes. Akhil Books, New Delhi: 292 pp.

Smith, M.A. (1943). The Fauna of British India, Ceylon and Burma, Including the whole of the Indo-Chinese Sub-Region. Reptilia and Amphibia. 3 (Serpentes). Taylor \& Francis, London: $583 \mathrm{pp}$.

Somaweera, R. (2006). The Snakes of Sri Lanka [in Sinhala]. Wildlife Heritage Trust of Sri Lanka, Colombo: 270 pp.

Taylor, E.H. (1950). The Snakes of Ceylon. University of Kansas Science Bulletin, 33 (14): 519-603.

Theobald, W. (1876). Descriptive catalogue of the reptiles of British India. Thacker, Spink \& Co., Calcutta: 238 pp.

Uetz, P., S. Cherikh, G. Shea, I. Ineich, P.D. Campbell et al. (2019). A global catalog of primary reptile type specimens. Zootaxa, 4695 (5): 438-450.

Wall, F. (1919). Notes on a collection of snakes made in the Nilgiri hills and adjacent Wynaad. Journal of the Bombay Natural History Society, 26 (2): 552-584.

Wall, F. (1921). Ophidia Taprobanica or the Snakes of Ceylon. Colombo Museum, H. R. Cottle, government printer, Colombo: $581 \mathrm{pp}$.

Wall, F. (1924). A Hand-list of the Snakes of the Indian Empire. Part 3. Journal of the Bombay Natural History Society, 29 (4): 864-878.

Wallach, V., K.L. Williams, and J. Boundy (2014). Snakes of the World: A Catalogue of Living and Extinct Species. CRC Press, Taylor \& Francis Group, Florida: 1237 pp.

Whitaker, R. (1978). Common Indian snakes: a field guide. Macmillan Books, New Delhi: 155 pp.

Whitaker, R. and A. Captain (2008). Snakes of India: The Field Guide. Draco Books, New Delhi: 495 pp.

Willey, A. (1906). Terrestrial Colubridae of Ceylon. Spolia Zeylanica, 3 (11): 227-234. 
Appendix I. Other specimens examined

Liopeltis calamaria (30 ex.): Sri Lanka (n=6): Ceylon (Sri Lanka): BMNH 1946.1.5.60 \& 1946.1.21.64 (syntypes), 1846.12.2, NMW 26966:1-2; Diyatalawa, Uva Province: BMNH 1933.12.6.13. Peninsular India (n=16): Madras Presidency: ZSI 8734, 8735, BMNH 1866.12.15.8; Tinnevelly Hills: ZSI 4421; Hosur, Mysore: BMNH 1925.4.2.51; Kotagiri, Nilgherries: BMNH 1891.11.27.12; Catounni, Bangalore: BMNH 1931.6.15.16-18; Matheran: BMNH 1869.8.28.146a-c; Wynaad: BMNH 1922.5.25.532 (lectotype of Liopeltis c. indica), ZSI 18608 (paralectotype of Liopeltis c. indica). Nallamalai, Andhra Pradesh: ERMR29a; Andhra Pradesh, Kambakkam: MAD 8-31-VII-22. Himalaya / Nepal (n=7): Songara, Gonda: ZSI 16385; Kurkhana, Uttar Pradesh: ZSI 16437; Melaghat Almorah: ZSI 16438; BMNH 1940.3.4.22-23; Punjab: BMNH 1948.1.7.5, 1922.6.14.1. Unknown locality (probably India) (n=1): BMNH 1946.1.5.36 (holotype of Cyclophis nasalis).

Liopeltis frenata (1 ex): India: Khasi Hills: BMNH 1946.1.1.72 (holotype).

Liopeltis pallidonuchalis (4 ex): Vietnam: Gia Lai: ZMMU R-15682 (holotype); Thua Thien-Hue: ZFMK 83105 (paratype), DTU 307 (paratype); Quang Binh: VNUH 9.7.06-1.

Liopeltis rappi (5 ex): India: Sikkim: BMNH 1946.1.5.61 (holotype); Simla: NMW 26963:1; Kulu at Kategarh: NMW 26963:2; Myanmar: Rangoon: NMW 26962:1-3.

Liopeltis tricolor (14 ex): Indonesia: Java: BMNH 1946.1.5.34, 69.12.4.127 (Syntypes), BMNH uncat. (holotype of Ablabes schlegelii), NMW 26967:1-4; Sumatra: NMW 26968:2, SMF 81197, ZFMK 33533; Kalimantan: NMW 26968:3; Banka: RMNH 554; East Indian Archipelago: RMNH 4036; Peninsular Malaysia: Penang: NMW 26968:1. 
- blank page - 